\title{
PROJEKTOWANIE WIĄZARÓW Z CEOWNIKÓW I KĄTOWNIKÓW RÓWNORAMIENNYCH O WEZLACH TYPU K. CZĘŚĆ 2: WĘZLY PASA GÓRNEGO
}

\begin{abstract}
W artykule przedstawiono sposób połączenia prętów skratowania z pasem górnym kratownicy. W połączeniu tym pręty łączy się za pomocą wkładki wykonanej z kątownika równoramiennego, przyspawanego do ceowego przekroju pasa. Nośność krzyżulców sprawdza się podczas oceny prętów kratownicy. Nośność styku krzyżulców ze ściankami wkładki ustala się w sposób analogiczny, jak omówiony w [12]. Nośność wkładki wyznacza się traktując ją, jako belkę zginaną i ściskaną (lub rozciąganą) umownymi siłami skupionymi.

Słowa kluczowe: kratownice stalowe, projektowanie węzłów kratownic z prętów o przekroju otwartym, mimośrodowe połączenie prętów skratowania z pasem górnym kratownicy
\end{abstract}

\section{Wstęp}

W pierwszej części artykułu [12] przedstawiono informacje ogólne, zasady kształtowania elementów, węzłów, a także omówiono projektowanie i obliczanie węzłów pasa dolnego i zestawiono cytowane piśmiennictwo.

\section{Kształtowanie węzłów pośrednich}

Na rysunku 1 pokazano kształt takiego węzła w wypadku krzyżulców, dołączanych do pasa górnego za pośrednictwem wkładki, przy czym obydwa kątowniki są rozmieszczone narożami od strony środnika ceowego przekroju pasa. Zastosowanie takiej wkładki, wyciętej z równoramiennego kątownika o grubych ramionach, umożliwia dogodny dostęp podczas układania spoin pachwinowych

\footnotetext{
${ }^{1}$ Autor do korespondencji / corresponding author: Jan Bródka, 01-452 Warszawa, ul. Księcia Janusza 41/43 m. 152, jan.brodka@gmail.com

2 Andrzej Wojnar, Politechnika Rzeszowska, 35-959 Rzeszów, ul. Powstańców Warszawy 12, awojnar@prz.edu.pl
} 
między krzyżulcami i wkładką. Bezpośrednie dołączanie krzyżulców do środnika pasa, jak też stosowanie do ich mocowania blachy węzłowej prowadzi do niekorzystnych sytuacji podczas wytwarzania elementów.

Natomiast na rysunku 2 pokazano kształt węzła w wypadku krzyżulców o narożach, rozmieszczonych zawsze od tej samej strony.

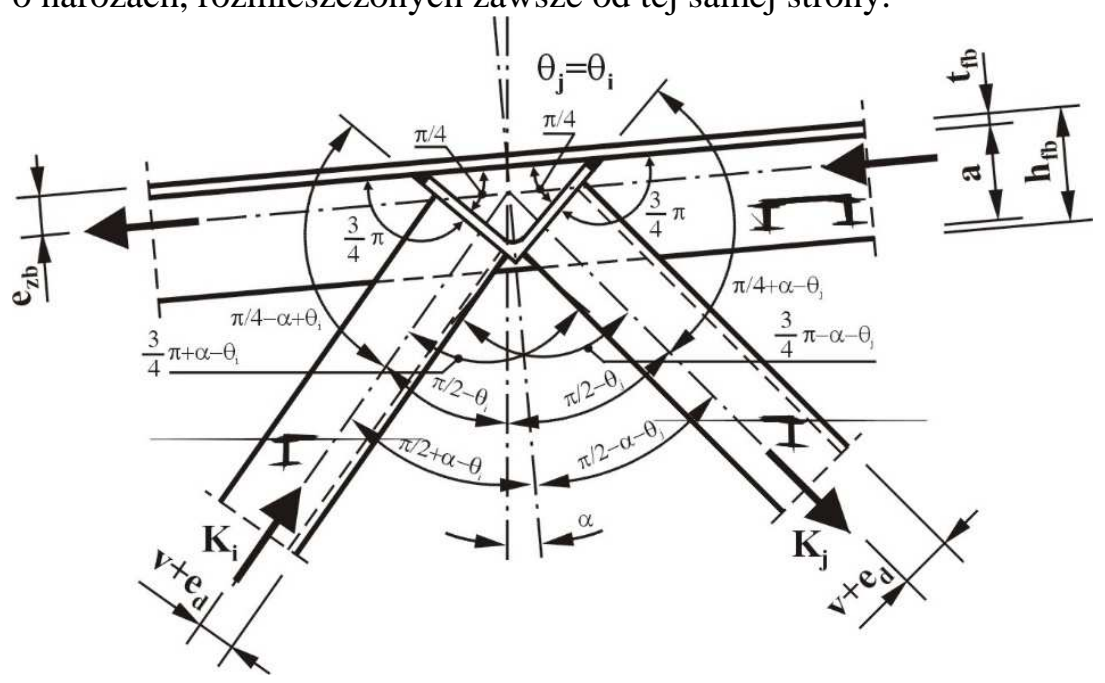

Rys. 1. Połączenie krzyżulców z pasem górnym kratownicy - kątowniki rozmieszczone narożami od strony środnika ceowego przekroju pasa

Fig. 1. Connection between brace members and upper channel section chord of truss

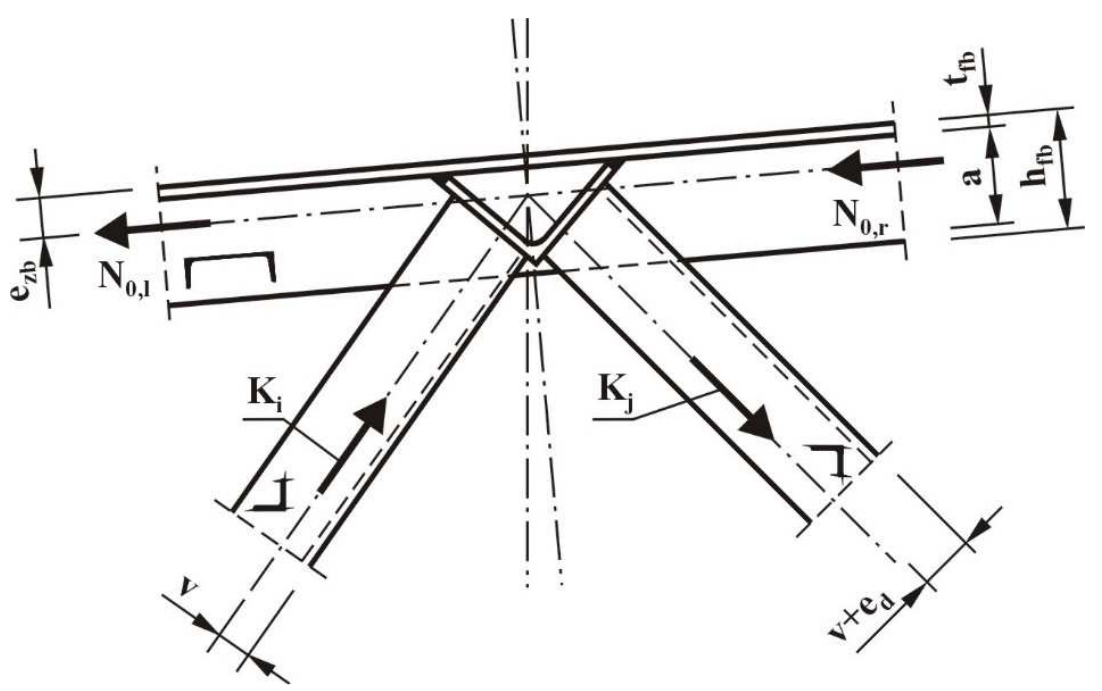

Rys. 2. Połączenie krzyżulców z pasem górnym kratownicy - kątowniki rozmieszczone narożami od tej samej strony

Fig. 2. Another connection between brace members and upper channel section chord of truss 
Układ rozmieszczenia naroży krzyżulców jest wynikiem ukształtowania prętów skratowania w węzłach pasa dolnego (patrz pierwszą część artykułu).

Aby zapewnić hermetyczne zamknięcie wnętrza wkładki bez dodatkowych denek z cienkich pasków blachy wymiar zastosowanego kątownika powinien spełniać warunek

$$
a=h_{f b}-t_{f b}-10 \mathrm{~mm}
$$

w którym:

$$
\begin{aligned}
& \text { a - wysokość wkładki, odkładana prostopadle do osi pasa górnego, } \\
& \mathrm{h}_{\mathrm{fb}} \text { - szerokość stopki ceownika, zastosowanego na pas, } \\
& \mathrm{t}_{\mathrm{fb}} \text { - grubość środnika tego ceownika. }
\end{aligned}
$$

Aby wykonać taką wkładkę, trzeba ją wyciąć z kątownika równoramiennego, którego szerokość ramienia wynosi co najmniej $a_{i}=a \sqrt{ } 2$. Ten wymiar zwykle umożliwia dołączenie krzyżulców w sposób, pokazany na rysunkach 1 i 2. Jeżeli tak nie jest to można pręty skratowania dołączyć względem pasa, stosując nieduży mimośród, odkładany względem jego osi w stronę środnika ceownika, zastosowanego na pas. Jednak w takiej sytuacji odstęp między ścianką pasa a narożem krzyżulca powinien pozwalać na ułożenie tam spoiny pachwinowej bez nakładania się na spoinę szerokobruzdową, łączącą wkładkę z pasem.

Na rysunku 1 wskazano zależności między kątami, które wynikają z geometrii węzła. Są one związane z geometrią węzła pasa dolnego i są wykorzystywane do dalszych obliczeń. Mają znaczenie:

$\theta_{i}$ - kąt nachylenia drugiego (czwartego lub szóstego) krzyżulca od podpory kratownicy względem pasa dolnego (patrz schemat kratownicy na rys. $1 \mathrm{w}$ [12])

$\theta_{\mathrm{i}}=\theta_{\mathrm{j}}$,

$\theta_{\mathrm{j}}$ - kąt nachylenia drugiego (czwartego lub szóstego) krzyżulca.

Ponadto występują symbole:

$\alpha$ - kąt nachylenia pasa górnego względem pasa dolnego (zwykle około 5\% nachylenia spadku połaci dachowej),

$\mathrm{e}_{\mathrm{zb}}$ - odstęp środka ciężkości ceownika pasa od zewnętrznego brzegu jego środnika,

$\mathrm{e}_{\mathrm{d}}$ - mimośród krzyżulca (patrz rys. 1 i 2),

v - odstęp środka ciężkości kątownika krzyżulca od jego zewnętrznego naroża wzdłuż osi symetrii przekroju.

\section{Nośność węzła pośredniego}

Ustala się, rozpatrując nośności jego części składowych oraz ich złączy spoinami pachwinowymi lub czołowymi. 


\subsection{Nośność połączeń spawanych}

Korzysta się z procedury, omówionej w [3], lecz dostosowanej do węzłów typu K w pierwszej części artykułu (patrz [12]). Aby ocenić podatność połączenia krzyżulców z wkładką, na rys. 3 pokazano trzy sytuacje projektowe położenia krzyżulców w węźle: (a) pasa dolnego, (b) pasa górnego według rys 1 oraz (c) pasa górnego według rys. 2 .

a)

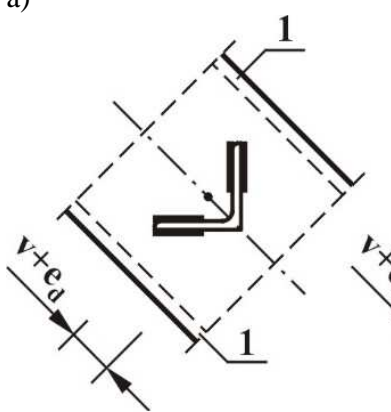

b)

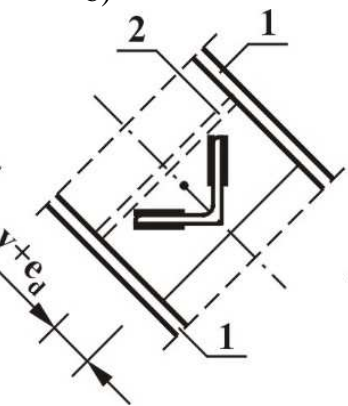

c)

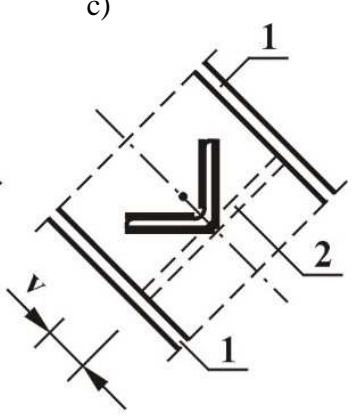

Rys. 3. Położenie krzyżulców z pasem dolnym (a) i górnym (b, c) kratownicy

Fig. 3. Connection between brace members and lower (a) and upper (b, c) channel section chord of truss

Sytuacja (a) jest wzorcowa, w odniesieniu do której podano procedurę oceny długości współpracujących spoin pachwinowych [12]. Patrząc w kierunku pasa dolnego, stwierdza się, że naroże kątownika dołączone do środnika pasa jest elementem podatnym, a wiec narażonym na podatność płytową ścianki pasa. Długość współpracującą odcinka spoiny ustalono, biorąc pod uwagę strefę ograniczonej podatności swobodnych brzegów ramion kątowników w pobliżu sztywnych podpór (stopek ceownika, oznaczonych jako 1).

Sytuacja projektowa (b) różni się od wzorcowej tym, że swobodne brzegi ramion kątowników mają dodatkowe podparcie ścianką wkładki (oznaczoną jako 2). To powoduje, że brzegi znajdują się strefie zmniejszonej podatności płytowej. W celu uproszczenia dalszych działań proponuje się oceniać współpracującą długość odcinków spoin pachwinowych w taki sam sposób, jak w odniesieniu do węzłów pasa dolnego [12]. Będzie więc w wypadku krzyżulca obciążonego siłą $\mathrm{K}_{\mathrm{j}}$ : $\mathrm{d}_{\mathrm{f}}=1,1_{\mathrm{b}} / \sin \left(0,75 \pi-\alpha-\theta_{\mathrm{j}}\right)$ oraz $\mathrm{w}$ wypadku siły $\mathrm{K}_{\mathrm{i}}$ : $\mathrm{d}_{\mathrm{f}}=1,1_{\mathrm{b}} / \sin \left(0,75 \pi+\alpha-\theta_{\mathrm{i}}\right)$.

Natomiast w sytuacji projektowej (c) dodatkowe podparcie ścianka wkładki występuje w narożu kątownika, zastosowanego na krzyżulec. To czyni, że połączenie spawane tego pręta $\mathrm{z}$ wkładką jest prawie sztywne. Aby posługiwać się oceną połączenia, omówioną w [12], proponuje się przyjmować długość współpracującą odcinków spoin pachwinowych o wartości: 


$$
b_{e f f}=b_{j}-t_{j}-r_{j} \text { albo } b_{e f f}=b_{i}-t_{i}-r_{i}
$$

przy czym:

$b_{i}$ lub $b_{j}$ - szerokość ramienia kątownika, zastosowanego na krzyżulec,

$t_{i}$ lub $t_{j}$ - grubość ramienia tego kątownika,

$\mathrm{r}_{\mathrm{i}}$ lub $\mathrm{r}_{\mathrm{j}}$ - promień zaokrąglenia między ramionami kątownika.

Mając ustalone wartości odcinków beff spoin pachwinowych, nośność połączenia każdego z krzyżulców z wkładką oblicza się metodą uproszczoną, podaną w PN-EN 1993-1-8.

Natomiast połączenie ramion wkładki ze środnikiem pasa górnego sprawdza się $\mathrm{w}$ wypadku czołowej spoiny szerokobruzdowej o grubości $\mathrm{a}_{\mathrm{w}}=\mathrm{t}_{\mathrm{a}}(\mathrm{gdzie}$ $\mathrm{t}_{\mathrm{a}}$ jest grubością ramienia kątownika równoramiennego, zastosowanego na wkładkę) w zależności od rozwiązania konstrukcyjnego według rys. 1 lub rys. 2.

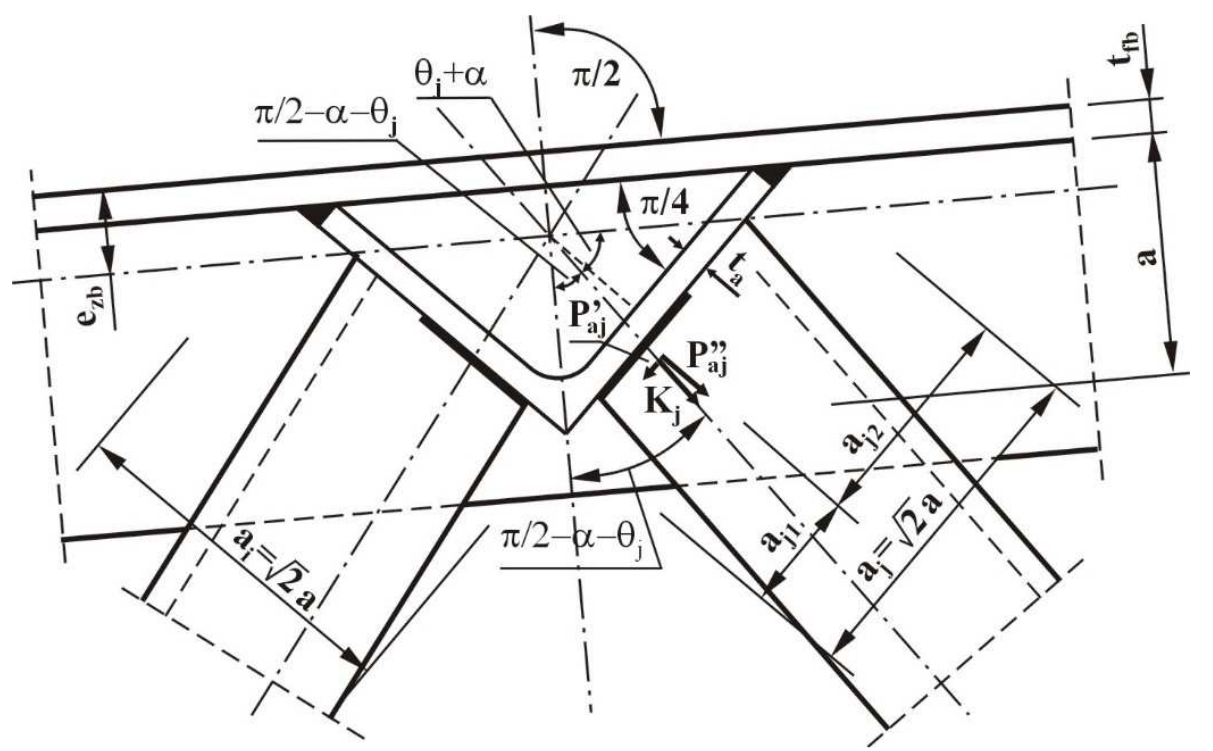

Rys. 4. Sposób połączenia prętów skratowania - opis w tekście

Fig. 4. Welded connection between brace members and upper chord of the truss - description in the text

W wypadku rysunku 1 wartości obciążenia złączy ustala się w sposób następujący (rys. 4):

a) Ustala się wartości składowych siły $\mathrm{K}_{\mathrm{j}}$ równoległej i prostopadłej do ścianki wkładki:

$$
P_{a j}^{\prime}=K_{j} \cos \left(0,75 \pi-\alpha-\theta_{j}\right)
$$




$$
P_{a j}^{\prime \prime}=K_{j} \sin \left(0,75 \pi-\alpha-\theta_{j}\right)
$$

b) Oblicza się położenie siły $\mathrm{K}_{\mathrm{j}} \mathrm{w}$ odniesieniu do naroża wkładki i spoiny szerokobruzdowej:

$$
\begin{aligned}
& a_{j 1}=\left(a+t_{f b}-e_{z b}\right) \cos (\pi / 4)\left[1-\tan \left(\theta_{j}+\alpha-\pi / 4\right)\right] \\
& a_{j 2}=\left(a+t_{f b}-e_{z b}\right) \cos (\pi / 4)\left[1+\tan \left(\theta_{j}+\alpha-\pi / 4\right)\right]+\left(e_{z b}-t_{f b}\right) \sqrt{2}
\end{aligned}
$$

c) Wyznacza się reakcje, powodowane siłą $\mathrm{P}_{\text {aj }} \mathrm{W}$ spoinie szerokobruzdowej i w ramieniu wkładki:

$$
\begin{aligned}
& R_{a j w}=P_{a j}^{\prime \prime}\left(a_{j 1}-0,5 t_{a}\right) /\left(a \sqrt{2}-t_{a}\right) \\
& R_{a j r}=P_{a j}^{\prime \prime}\left(a_{j 2}-0,5 t_{a}\right) /\left(a \sqrt{2}-t_{a}\right)
\end{aligned}
$$

d) Podobnie postępuje się w odniesieniu do krzyżulca, obciążonego siłą $\mathrm{K}_{\mathrm{i}}$, uzyskując odpowiednio:

$$
\begin{aligned}
& P_{a i}^{\prime}=K_{i} \cos \left(0,75 \pi+\alpha-\theta_{j}\right) \\
& P_{a i}^{\prime \prime}=K_{i} \sin \left(0,75 \pi+\alpha-\theta_{j}\right) \\
& a_{i 1}=\left(a+t_{f b}-e_{z b}\right) \cos (\pi / 4)\left[1-\tan \left(\theta_{j}-\alpha-\pi / 4\right)\right. \\
& a_{i 2}=\left(a+t_{f b}-e_{z b}\right) \cos (\pi / 4)\left[1+\tan \left(\theta_{j}-\alpha-\pi / 4\right)\right]+\left(e_{z b}-t_{f b}\right) \sqrt{2} \\
& R_{a i w}=P_{a i}^{\prime \prime}\left(a_{i 1}-0,5 t_{a}\right) /\left(a \sqrt{2}-t_{a}\right) \\
& R_{a i r}=P_{a i}^{\prime \prime}\left(a_{i 2}-0,5 t_{a}\right) /\left(a \sqrt{2}-t_{a}\right)
\end{aligned}
$$

przy czym $a_{j 1}$ i $a_{j 2}$ oraz $a_{i 1} i a_{i 2}$ odkłada się od naroża wkładki ku spoinie szerokobruzdowej (rys. 4). Znaczenie pozostałych symboli wyjaśniono uprzednio.

Siły wyznaczone z (3a), (5), (6a) i (8) służą do ustalenia obciążeń, przypadających na połączenia spoinami szerokobruzdowymi, mocującymi wkładkę w styku ze środnikiem pasa oraz na spoiny pachwinowe, ułożone wzdłuż ramion wkładki w styku ze stopką pasa. Wyznacza się w wypadku złączy:

a) szerokobruzdowych siły prostopadłe do ramion wkładki: 


$$
R_{a w}=R_{a i r} \quad \text { lub } \quad R_{a w}=R_{a j r}
$$

b) pachwinowych siły styczne do ramion wkładki:

$$
R_{a r}=R_{a j r}-P_{a i}^{\prime} \quad \text { lub } \quad R_{a r}=R_{a i r}-P_{a j}^{\prime}
$$

Naprężenia styczne $\mathrm{w}$ spoinach szerokobruzdowych złączy ramienia wkładki, obciążonego siłą $\mathrm{K}_{\mathrm{i}}$ lub ramienia wkładki, obciążonego siłą $\mathrm{K}_{\mathrm{j}}$, wynoszą odpowiednio:

$$
\tau_{1}=\frac{R_{a w}}{l_{w 1} a_{w 1}} \leq f_{v w, d}
$$

Naprężenia styczne w spoinach pachwinowych złączy ramienia wkładki, obciążonej siłą $\mathrm{K}_{\mathrm{i}}$, lub ramienia wkładki, obciążonej siłą $\mathrm{K}_{\mathrm{j}}$, wynoszą odpowiednio:

$$
\tau_{2}=\frac{R_{a w}}{2 l_{w 2} a_{w 2}} \leq f_{v w, d}
$$

przy czym:

$a_{w 1}=t_{a}-$ grubość spoiny szerokobruzdowej równa grubości ramienia wkładki,

$a_{\mathrm{w} 2}$ - grubość spoiny pachwinowej, ułożonej wzdłuż ramienia wkładki, ustalana w zależności od gatunku stali, zastosowanej na wkładkę i krzyżulec, zgodnie z wytycznymi, odnoszącymi się do elementów z kształtowników zamkniętych.

$1_{\mathrm{w} 1}=\mathrm{b}_{\mathrm{fb}}-2\left(\mathrm{t}_{\mathrm{wb}}+\mathrm{r}_{\mathrm{jb}}\right)-$ długość spoiny szerokobruzdowej,

$1_{\mathrm{w} 2}=\mathrm{a} \sqrt{2}-\mathrm{t}_{\mathrm{a}}-$ długość spoiny pachwinowej,

$\mathrm{b}_{\mathrm{fb}}$ - wysokość ceownika, zastosowanego a pas górny,

$\mathrm{r}_{\mathrm{jb}}$ - promień zaokrąglenia między środnikiem a stopką tego ceownika,

$\mathrm{t}_{\mathrm{wb}}$ - grubość stopki tego ceownika,

$\mathrm{f}_{\mathrm{vw}, \mathrm{d}}$ - obliczeniowa wytrzymałość spoiny pachwinowej na ścinanie według PNEN 1993-1-8.

Naprężenia według (11a) lub (11b) ustala się dwukrotnie, gdyż wartości sił $\mathrm{K}_{\mathrm{i}}$ oraz $\mathrm{K}_{\mathrm{j}}$ są różne. Jednak aby unikać pomyłek podczas wykonania złączy w rozpatrywanym węźle, zwykle przyjmuje się jednakowe grubości spoin pachwinowych $\mathrm{a}_{\mathrm{w} 2}$.

Jeżeli węzeł zaprojektowano według kształtu z rys. 2, to obciążenie złączy i ich naprężenia ustala się w sposób analogiczny. Jednak w takiej sytuacji projektowej należy zwrócić uwagę na to, że położenie spoin, łączących krzyżulce z wkładką, są różne, co wymaga zapewnienia im właściwego miejsca na ułożenie w pobliżu naroża wkładki. Odstęp wkładki od brzegu stopki ceownika powinien wynosić co najmniej $10 \mathrm{~mm}$. Wspomniana różnica wynika przy takich sa- 
mych wymiarach krzyżulców z faktu, że ich osie umieszcza się $\mathrm{w}$ stosunku do osi prętów kratownicy przy wartościach $\mathrm{v}+\mathrm{e}_{\mathrm{d}}$ lub tylko $\mathrm{v}$ (patrz rys. 2).

\subsection{Nośność części składowych węzła}

Nośność krzyżulców w węźle jest sprawdzana podczas oceny prętów kratownicy. Ich nośność w styku ze ściankami wkładki ustala się w sposób analogiczny, omówiony w odniesieniu do węzłów pasa dolnego. Ponadto należy wyznaczyć nośność wkładki podczas jej obciążenia jako belek zginanych i ściskanych (lub rozciąganych) od umownych sił skupionych $\mathrm{P}_{\text {ai }}$ lub $\mathrm{P}_{\text {aj. }}$.

Pod działaniem każdej z tych sił rozpatruje się wkładkę jako belkę swobodnie podpartą o długości $1=\sqrt{a}-t_{a}$, przy przekroju uzyskanym z zastosowanego kątownika równoramiennego po przycięciu jego ramion do odpowiedniego wymiaru ,a" (patrz rys. 4).

W takich belkach występują siły wewnętrzne:

$$
M_{r}=0,25 P_{a}^{\prime \prime}\left(b_{f b}-2 t_{w b}\right)
$$

oraz siły podłużne $\mathrm{N}_{\mathrm{r}}$ i poprzeczne $\mathrm{V}_{\mathrm{r}}$.

Gdy rozpatruje się wkładkę jako belkę, której pas obciąża siła $\mathrm{K}_{\mathrm{i}}$, wówczas:

$$
P_{a}^{\prime}=P_{a i}
$$

gdzie: siła podłużna $N_{r}=P_{a j r}-P_{a i}^{\prime \prime}$;

siła poprzeczna $V_{r}=0,5 P^{\prime \prime}{ }_{a j}$.

Natomiast gdy rozpatruje się belkę, której pas jest obciążony siłą $\mathrm{K}_{\mathrm{j}}$, wówczas:

$$
P_{a}^{\prime \prime}=P_{a j}^{\prime \prime}
$$

gdzie: siła podłużna $N_{r}=P_{a i r}-P^{\prime \prime}{ }_{a j}$;

siła poprzeczna $V_{r}=0,5 P^{\prime \prime}{ }_{a j}$.

Siły podłużne, ściskająca lub rozciągająca, wywołują w przekrojach każdej z belek dodatkowe zginanie od momentu na ramieniu $\mathrm{e}_{\mathrm{r}}$, równym odstępowi tej siły od środka ciężkości przekroju belki. Wartość tego momentu o znaku, zależnym od kierunku siły podłużne, wynosi

$$
\Delta M_{r}= \pm N_{r} e_{r}
$$


W przekroju każdej belki wyznacza się naprężenia normalne we włóknie zewnętrznym:

$$
\begin{aligned}
& \sigma_{\max }=\left(M_{r}+\Delta M_{r} / W_{r, \text { min }}+N_{r} / A_{r} \leq f_{y r}\right. \\
& \sigma_{\text {min }}=\left(M_{r}+\Delta M_{r}\right) / W_{r, \text { max }}+N_{r} / A_{r} \leq f_{y r}
\end{aligned}
$$

Przy czym:

$\mathrm{A}_{\mathrm{r}}$ - pole przekroju wkładki,

$\mathrm{W}_{\mathrm{r}, \text { min }}=\mathrm{I}_{\mathrm{r}} / \mathrm{e}_{\mathrm{r}}-$ wskaźnik wytrzymałości przekroju wkładki od strony jej naroża,

$\mathrm{W}_{\mathrm{r}, \max }-\mathrm{I}_{\mathrm{r}} /\left(\mathrm{a} \sqrt{2}-\mathrm{e}_{\mathrm{r}}-\mathrm{t}_{\mathrm{a}}\right)-$ wskaźnik tego przekroju od strony spoiny szerokobruzdowej,

I $\quad$ - moment bezwładności tego przekroju,

$\mathrm{f}_{\mathrm{yr}}$ - granica plastyczności stali, zastosowanej na wkładkę.

Siła poprzeczna powoduje powstanie naprężenia ścinającego w środniku wkładki, które w przybliżeniu ocenia się jako:

$$
\tau=\frac{V_{r}}{t_{a}\left(a \sqrt{2}-t_{a}\right)}<f_{y r} / \sqrt{3}
$$

Wzorem Hubera należy ocenić bezpieczeństwo przekroju wkładki ze względu na naprężenia normalne i styczne. Tak ustalone naprężenie zredukowane należy brać pod uwagę podczas oceny wartości $n=\sigma_{\text {red }} / f_{y r}$ wtedy, kiedy wyznacza się współczynnik $\mathrm{k}_{\mathrm{m}}=1,3(1-\mathrm{n}$ ) $\leq 1$ (patrz wymaganie $\mathrm{w}$ Tablicy 7.13 PN-EN 1993-1-8).

Kątowniki równoramienne na wkładki należy dobierać o takiej grubości ich ramienia, aby współczynnik $\mathrm{k}_{\mathrm{m}}$ miał wartość, przy której nie jest potrzebne wzmacnianie jego ścianki na miejscowe obciążenie siłami $K_{i}>\left|K_{j}\right|$.

Nośność pasa górnego $\mathrm{w}$ węźle sprawdza się, biorąc pod uwagę ocenę, podana w PN-EN 1993-1-8 (Tablica7.24). Szczegółowo zostało to omówione $\mathrm{w}[4]$.

\section{Węzły podporowe}

W wypadku układu prętów kratownicy według rys. 1a (patrz [12]) węzeł podporowy jest kształtowany, jak pokazano na rys. 5. Obciążenie węzła jest o wartościach zerowych sił wewnętrznych. Połączenie pasa dolnego ze słupkiem podporowym wykonuje się na spoiny pachwinowe, ułożone wzdłuż całego obwodu ceownika. Ich grubości przyjmuje się ze względów konstrukcyjnych.

Natomiast węzeł podporowy w wypadku układu prętów kratownicy z rys. $1 \mathrm{~b}$ jest kształtowany, jak pokazano na rys. 6. Geometria węzła typu $\mathrm{K}$ jest dostoso- 
wana do geometrii elementu kratowego, podpartego na słupie. Jako słupek podporowy zazwyczaj stosuje się ceownik takiego samego rozmiaru jak pas górny, lecz dodatkowo wzmocniony blachami na przedłużeniu stopek. To wynika z mimośrodowego obciążenia tego elementu i konieczności prawidłowego połączenia śrubami jego blachy poziomej ze słupem. Środnik słupka trzeba wzmocnić blachą, połączoną spoinami pachwinowymi ułożonymi w jego narożach, gdyż przy dużej sile w krzyżulcu lokalne oddziaływanie występuje przy współczynniku $\mathrm{k}_{\mathrm{m}}$ $<1,0$. Wartość $n$ ustala się przy $\sigma_{0, E d}=\mathrm{N}_{\mathrm{c}} /\left(\mathrm{t}_{\mathrm{p}} \mathrm{b}_{\mathrm{p}}\right)$, przy czym $\mathrm{N}_{\mathrm{c}}$ jest reakcją wiąza$\mathrm{ra}, \mathrm{b}_{\mathrm{p}}$, wysokością blachy wzmacniającej oraz $\mathrm{t}_{\mathrm{p}}$ jej grubością.

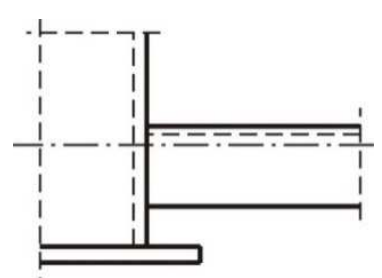

Rys. 5. Węzeł podporowy kratownicy jak na rys. 1a [12]

Fig. 5. The support node of the truss (according to fig. 1a [12])

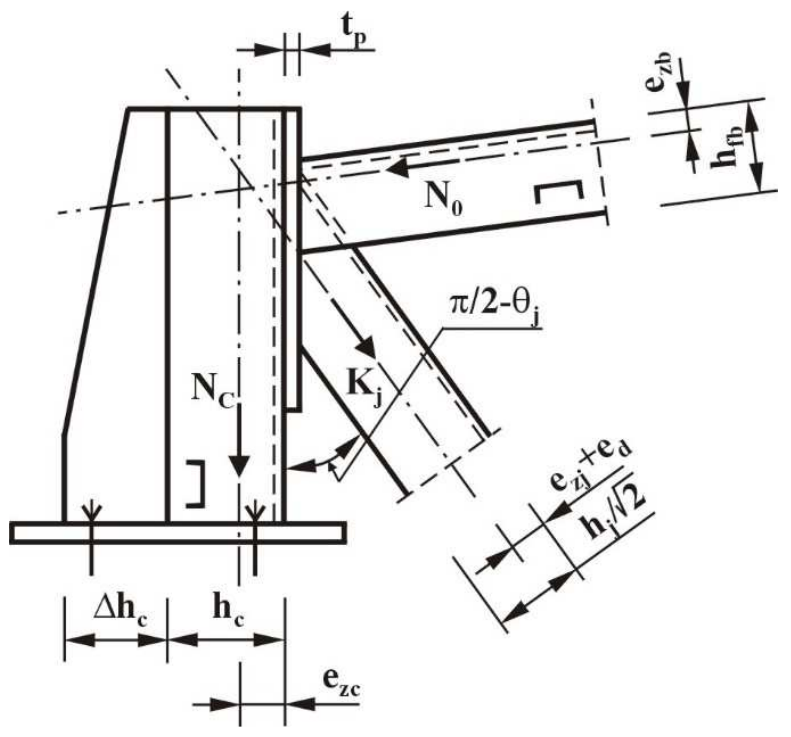

Rys. 6. Węzeł podporowy kratownicy jak na rys. 1b [12]

Fig. 6. The support node of the truss (according to fig. 1b [12])

Połączenie krzyżulca z blachą wzmacniającą ocenia się zarówno w wypadku połączenia spawanego, jak też części składowych węzła w sposób omówiony w odniesieniu do węzła pośredniego pasa dolnego. 
Połączenie pasa górnego z blachą wzmacniającą na spoiny pachwinowe ocenia się w sposób, odnoszący się do krzyżulców węzła pasa dolnego, omówiony w [4]. Siła ściskająca w skrajnym przedziale pasa górnego jest stosunkowo niedużej wartości tak, że grubość spoin pachwinowych może być zmniejszona w stosunku do grubości, przyjmowanych podczas obliczania krzyżulca skrajnego.

Słupek podporowy przenosi reakcję wiązara jako element ściskany mimośrodowo. Ze względu na jego małą długość pomija się wpływ stateczności.

Jednak w wypadku umieszczenia podpory według rys. 5, ten element wymaga uwzględnienia skutków niestateczności ogólnej. W takiej sytuacji projektowej słupek warto wykonać o przekroju zamkniętym. Stosuje się zwykle przekrój skrzynkowy z dwóch ceowników lub kształtownik zamknięty o przekroju kwadratowym.

\section{Węzeł kalenicowy}

Węzeł pasa górnego w kalenicy (zwykle montażowy) kształtuje się według układu części składowych, pokazanego na rys. $7 \mathrm{w}$ wypadku krzyżulców, odpowiadających węzłowi pasa dolnego z rys. 2 (patrz [12]). Jeżeli umieszczenie krzyżulców odpowiada rys. 3 z [12], to rozwiązanie węzła kalenicowego nie zmienia się poza sposobem ułożenia tych prętów. Należy przyjmować dużą grubość blach styku, zwykle 16 do $20 \mathrm{~mm}$, aby węzeł można było traktować jako niepodatny. Wówczas blachy czołowe, połączone śrubami, są wzajemnie dociskane. Obliczanie połączeń na spoiny pachwinowe przeprowadza się w sposób omówiony w wypadku węzła podporowego w poziomie pasa górnego, lecz w wypadku krzyżulców beff jest przyjmowane z zależności (2). Kątownik krzyżulca ze względu na ujednolicenie przekrojów prętów skratowania jest przyjmowany z nadmiarem.

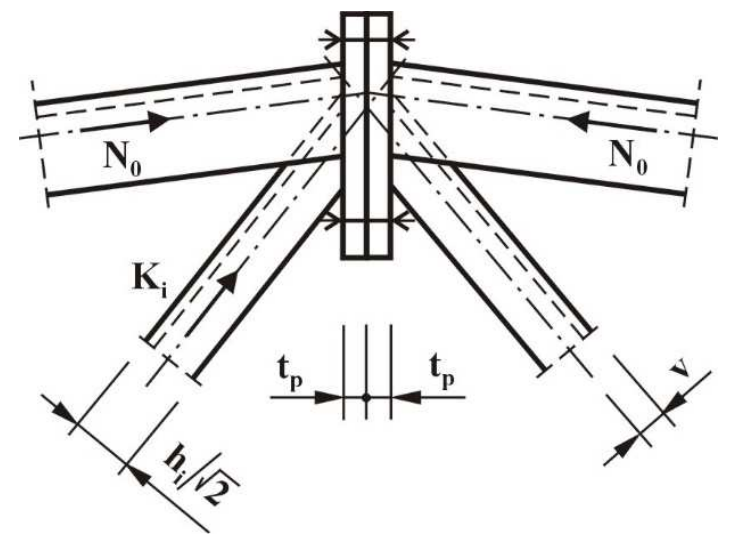

Rys. 7. Styk montażowy pasa górnego kratownicy

Fig. 7. The connection of upper chord of the truss 


\section{Przykład obliczania węzła pośredniego}

Rozpatruje się pierwszy od podpory węzeł według rysunku wiązara (patrz [12]). Siły podłużne w krzyżulcach wynoszą: $\mathrm{K}_{\mathrm{i}}=-360,5 \mathrm{kN}$ i $\mathrm{K}_{\mathrm{j}}=202,6 \mathrm{kN}$.

Pas górny zaprojektowano $\mathrm{z}$ ceownika o równoległych ściankach UP 360, którego cechy geometryczne są następujące: $\mathrm{b}_{\mathrm{fb}}=360 \mathrm{~mm}, \mathrm{~h}_{\mathrm{fb}}=110 \mathrm{~mm}$, $\mathrm{t}_{\mathrm{fb}}=12 \mathrm{~mm}, \mathrm{t}_{\mathrm{wb}}=17 \mathrm{~mm}, \mathrm{e}_{\mathrm{zb}}=29,4 \mathrm{~mm}, \mathrm{r}_{\mathrm{jb}}=18 \mathrm{~mm}$.

Krzyżulce zaprojektowano z kątowników L120x120x12. Ich cechy geometryczne są następujące: $A_{i}=A_{j}=27,5 \mathrm{~cm}^{2}, v=4,8 \mathrm{~cm}, t_{i}=t_{j}=12 \mathrm{~mm}$, $b_{i}=b_{j}=120 \mathrm{~mm}, e_{d}=8,27 \mathrm{~mm}$ (patrz [12]).

Węzeł ma kształt pokazany na rys. $1 \mathrm{z}$ wkładką, wyciętą z kątownika 180x180x16 mm., którego pole przekroju $\mathrm{A}=55,4 \mathrm{~cm}^{2}$. Cechy geometryczne wkładki ustalono o wartościach:

Szerokość boku po odcięciu pasm: $\mathrm{a}=110-12-10=88 \mathrm{~mm}$, pole przekroju zredukowanego $\mathrm{A}_{\mathrm{r}}=5540-2 \cdot 16(180-88 \sqrt{2}-16)=3249 \mathrm{~mm}^{2}$. Dalsze cechy obliczono, pomijając zaokrąglenie między ramionami kątownika: $\mathrm{e}_{\mathrm{r}}=32,6 \mathrm{~mm}, \mathrm{I}_{\mathrm{r}}=771,9 \mathrm{~cm}^{4}, \mathrm{~W}_{\mathrm{r}, \min }=101,8 \mathrm{~cm}^{3}, \mathrm{~W}_{\mathrm{r}, \max }=236,9 \mathrm{~cm}^{3}$.

Funkcje kątów wynoszą:

$\theta_{\mathrm{i}}=\theta_{\mathrm{j}}=47^{\circ} 7^{\prime} 6^{\prime \prime}, \quad \alpha=4^{\circ} 49^{\prime}$,

$\sin \left(3 \pi / 4+\alpha-\theta_{\mathrm{j}}\right)=0,9988$,

$\cos \left(3 \pi / 4+\alpha-\theta_{\mathrm{j}}\right)=-0,05$,

$\sin \left(3 \pi / 4-\alpha-\theta_{\mathrm{j}}\right)=0,9923$,

$\cos \left(3 \pi / 4-\alpha-\theta_{\mathrm{j}}\right)=0,1236$,

$\tan \left(\theta_{\mathrm{j}}+\alpha-\pi / 4\right)=0,1246$,

$\tan \left(\theta_{\mathrm{j}}-\alpha-\pi\right)=0,05$.

Pas górny, wkładkę i krzyżulce projektuje się ze stali S355 o f $\mathrm{y}=355 \mathrm{MPa}$ if $_{\mathrm{u}}=490 \mathrm{MPa}$.

A. Rozpatruje się obciążenie krzyżulca $\mathrm{K}_{\mathrm{i}}=-360,5 \mathrm{kN}$.

Ocena długości współpracującej odcinka spoiny pachwinowej (patrz [12]):

$d_{f 1}=3,14 \cdot 120 /(4 \cdot 0,9988)=94,3 \mathrm{~mm}$

$d_{f 2}=2 \cdot 120 /(\sqrt{2} \cdot 0,9988)=169,9 \mathrm{~mm}$

$d_{f}=0,5(94,3+169,9) \cdot 132,1 \mathrm{~mm}$

$b_{\text {eff }}=0,6124 \cdot 132,1=80,9 \mathrm{~mm}$

Naprężenia składowe wynoszą:

$$
\begin{aligned}
& \sigma=\frac{360500 \cdot 0,9988}{2 \cdot 12 \cdot 80,9}=185,4 \mathrm{MPa} \\
& \tau=1,15 \frac{360500 \cdot 0,05}{2(120-0,5 \cdot 12)}=6,6 \mathrm{MPa}
\end{aligned}
$$




$$
\sigma_{\text {red }}=\sqrt{185,4^{2}+3 \cdot 6,6^{2}}=185,8 \mathrm{MPa}<355 \mathrm{MPa}
$$

Sprawdzenie spoin pachwinowych o grubości $\mathrm{a}_{\mathrm{w}}=5 \mathrm{~mm}$ :

$$
\begin{aligned}
& A_{w}=4 \cdot 5 \cdot 80,9=1618 \mathrm{~mm}^{2} \\
& V_{1}=360,5 \cdot 0,05=18 \mathrm{kN} \\
& V_{2}=360,5 \cdot 0,9988=360,1 \mathrm{kN} \\
& \tau_{1}=18000 / 1618=11,1 \mathrm{MPa} \\
& \tau_{2}=360100 / 1618=222,6 \mathrm{MPa} \\
& \tau_{\max }=\sqrt{11,1^{2}+222,6^{2}}=222,9 \mathrm{MPa}<490 /(\sqrt{3} \cdot 0,8 \cdot 1,25)=283,2 \mathrm{MPa}
\end{aligned}
$$

W wypadku krzyżulca obciążonego siłą $\mathrm{K}_{\mathrm{j}}=202,6 \mathrm{kN}$ naprężenia będą mniejsze, gdyż siła podłużna jest mniejsza, a wartości obliczeniowych przekrojów różnią się nieznacznie.

Sprawdzenie pod obciążeniem lokalnym ścianek wkładki (patrz [12]).

Wartość nośności $\mathrm{N}_{\mathrm{i}, \mathrm{Rd}}^{*}$ :

Uplastycznienie środnika wkładki i zginanie brzegów pasa są niemiarodajne, lecz jest przy:

- przebiciu pasa wkładki o jej szerokości a $\sqrt{2}-\mathrm{t}_{\mathrm{a}}=88 \sqrt{2}-16=108,4 \mathrm{~mm}$ :

$$
\begin{aligned}
& b_{e p}=\frac{10 \cdot 80,9}{\sqrt{2} \cdot 108,4 / 16}=84,4 \mathrm{~mm}>\frac{80,9}{\sqrt{2}}=57,2 \mathrm{~mm} \\
& N_{1, R d}=2 \frac{355 \cdot 16}{\sqrt{3}}(2 \cdot 16+2 \cdot 57,2)=961,3 \cdot 10^{3} \mathrm{~N}=964,3 \mathrm{kN}
\end{aligned}
$$

Wartość nośności $\mathrm{N}^{* *}{ }_{\mathrm{i}, \mathrm{Rd}}$ :

$$
\begin{aligned}
& N_{1, R d}=2 \cdot 1,0 \cdot 355 \cdot 16^{2}(2 \cdot 80,9 / 108,4+4 \sqrt{1-16 / 108,4})=871,5 \cdot 10^{3} N=871,5 \mathrm{kN} \\
& N_{i, R d}=0,5(961,3+871,5)=436,2 \mathrm{kN}>360,1 \mathrm{kN}
\end{aligned}
$$

W wypadku obciążenie wkładki siłą $\mathrm{K}_{\mathrm{j}}=202,6 \mathrm{kN}$ jest:

$N_{j, R d}=436,2 \mathrm{kN}>202,6 \cdot 0,9963=201 \mathrm{kN}$

B. Sprawdzenie nośności połączenia wkładki z pasem.

Sprawdzenie pod obciążeniem $\mathrm{K}_{\mathrm{i}}=-360,5 \mathrm{kN}$.

a) Ustala się wartości sił składowych (wzory (6)):

$$
\begin{aligned}
& P_{a i}^{\prime}=K_{i} \cos \left(3 \pi / 4+\alpha-\theta_{j}\right)=-360,5(-0,05)=18 \mathrm{kN} \\
& P_{a i}^{\prime \prime}=K_{i} \sin \left(3 \pi / 4+\alpha-\theta_{j}\right)=-360,6 \cdot 0,9988=-360,1 \mathrm{kN}
\end{aligned}
$$

b) Oblicza się odcinki w celu ustalenia położenia siły $\mathrm{K}_{\mathrm{i}}$ (wzory (7)):

$$
\begin{aligned}
& a_{i 1}-\left(a+t_{f b}-e_{z b}\right) \cos (\pi / 4)[1-\tan (\theta-\alpha-\pi / 4)]= \\
& (88+12-29,4) 0,7071(1-0,05)=47,4 \mathrm{~mm}>120 / \sqrt{3}-48-8,27=28,6 \mathrm{~mm}
\end{aligned}
$$


$a_{i 2}=\left(a+t_{f b}-e_{z b}\right) \cos (\pi / 4)\left[1+\tan \left(\theta_{j}-\alpha \pi / 4\right)\right]+\left(e_{z b}-t_{f b}\right) \sqrt{2}-$ $(88+12-29,4) 0,7071(1+0,05)+(29,4-12) \sqrt{2}=77 \mathrm{~mm}>48+8,27=56,27 \mathrm{~mm}$

c) Oblicza się reakcje od obciążenia siłą $\mathrm{P}_{\text {ai }}$ (wzory (8)):

$$
\begin{aligned}
& R_{a i w}=\frac{a_{i 1}-0,5 t_{a}}{a \sqrt{2}-t_{a}} P_{a i}^{\prime}=\frac{-47,4-0,5 \cdot 16}{88 \sqrt{2}-16} \cdot 360,1=-130,9 \mathrm{kN} \\
& R_{\text {air }}=\frac{a_{i 2}-0,5 t_{a}}{a \sqrt{2}-t_{a}} P_{a i}^{\prime}=\frac{-77,4-0,5 \cdot 16}{88 \sqrt{2}-16} \cdot 360,1=-229,2 \mathrm{kN}
\end{aligned}
$$

Sprawdzenie pod obciążeniem $\mathrm{K}_{\mathrm{j}}=202,6 \mathrm{kN}$ :

$\mathrm{P}^{\prime}{ }_{\mathrm{aj}}=\mathrm{K}_{\mathrm{j}} \cos \left(3 \pi / 4-\alpha-\theta_{\mathrm{j}}\right)=202,6 \cdot 0,1236=25 \mathrm{kN}$,

$\mathrm{P}^{\prime \prime}{ }_{\text {aj }}=\mathrm{K}_{\mathrm{j}} \sin \left(3 \pi / 4 \alpha-\theta_{\mathrm{j}}\right)=202,6 \cdot 0,9923=201 \mathrm{kN}$,

$\mathrm{a}_{\mathrm{j} 1}=\left(\mathrm{a}+\mathrm{t}_{\mathrm{fb}}-\mathrm{e}_{\mathrm{zb}}\right) \cos (\pi / 4)\left[1-\tan \left(\theta_{\mathrm{j}}+\alpha-\pi / 4\right)\right]=$

$(88+12-29,4) 0,7071(1-0,1246)=43,7 \mathrm{~mm}>28,6 \mathrm{~mm}$,

$\mathrm{a}_{\mathrm{j} 2}=\left(\mathrm{a}+\mathrm{t}_{\mathrm{fb}}-\mathrm{e}_{\mathrm{zb}}\right) \cos (\pi /)\left[1-\tan \left(\theta_{\mathrm{j}}+\alpha-\pi / 4\right)+\left(\mathrm{e}_{\mathrm{zb}}-\mathrm{t}_{\mathrm{fb}}\right) \sqrt{2}=\right.$

$(88+12-29,4) \cdot 0,7071(1+0,1246)+29,4-12) \sqrt{ } 2=$

$=80,2 \mathrm{~mm}>56,27 \mathrm{~mm}$,

$$
\begin{aligned}
& R_{a j w}=\frac{a_{i 1}-0,5 t_{a}}{a \sqrt{2}-t_{a}} P_{a j}^{\prime \prime}=\frac{43,7-0,5 \cdot 16}{88 \sqrt{2}-16} \cdot 201=66,2 \mathrm{kN} \\
& R_{a j r}=\frac{a_{i 2}-0,5 t_{a}}{a \sqrt{2}-t_{a}} P_{a j}^{\prime \prime}=\frac{80,2-0,5 \cdot 16}{88 \sqrt{2}-16} \cdot 201=133,9 \mathrm{kN}
\end{aligned}
$$

Siły obciążające spoiny szerokobruzdowe wynoszą (wzory (9)):

$\mathrm{R}_{\mathrm{aiw}}=\mathrm{R}_{\mathrm{air}}=-229,7 \mathrm{kN}$ lub $\mathrm{R}_{\mathrm{aw}}=\mathrm{R}_{\mathrm{ajr}}=133,9 \mathrm{kN}<|-229,7| \mathrm{kN}$

Długość spoiny ustala się jako:

$1_{\mathrm{w} 1}=\mathrm{b}_{\mathrm{fb}}-2\left(\mathrm{t}_{\mathrm{wb}}+\mathrm{r}_{\mathrm{fb}}\right)=360-2(17+18)=290 \mathrm{~mm}$.

Naprężenie ścinające w spoinie szerokobruzdowej silniej obciążonej wynosi przy $\mathrm{a}_{\mathrm{w} 1}=16 \mathrm{~mm}$ (wzór (11a))

$\max \tau_{1}=\mathrm{R}_{\mathrm{aw}} /\left(1_{\mathrm{w} 1} \mathrm{a}_{\mathrm{w} 1}\right)=229700 /(290 \cdot 16)=39,9 \mathrm{MPa}<283,2 \mathrm{MPa}$.

Siły obciążające spoiny pachwinowe (wzory (10)):

$\mathrm{R}_{\mathrm{ar}}=130,0 \mathrm{kN}$ lub $\mathrm{R}_{\mathrm{ar}}=\mathrm{R}_{\mathrm{air}}-\mathrm{P}_{\mathrm{aj}}^{\prime}=222,9-25=197,6 \mathrm{kN}>131,9 \mathrm{kN}$.

Długość spoiny ustala się jako: $1_{\mathrm{w} 2}=\mathrm{a} \sqrt{2}-\mathrm{t}_{\mathrm{a}}=88 \sqrt{2}-16=108,4 \mathrm{~mm}$,

Naprężenie przy $\mathrm{a}_{\mathrm{w} 2}=5 \mathrm{~mm}$ :

$$
\max \tau_{2}=\frac{R_{a r}}{2 \cdot l_{w 2} \cdot a_{w 2}}=\frac{197600}{2 \cdot 108,6 \cdot 5}=182,6 \mathrm{MPa}<283,2 \mathrm{MPa}
$$

C. Sprawdzenie nośności części składowych węzła

Sprawdzenie nośności ścianki pod obciążeniem $\mathrm{K}_{\mathrm{i}}=-360,5 \mathrm{kN}$.

Ustalenie wartości sił wewnętrznych od tego obciążenia przeprowadza się, korzystając z zależności:

$$
\begin{aligned}
& \mathrm{M}_{\mathrm{ri}}=0,25 \mathrm{P}^{\prime}{ }_{\mathrm{ai}}\left(\mathrm{b}_{\mathrm{fb}}-\mathrm{t}_{\mathrm{wb}}\right)=0,25 \cdot 360,1(360-17)=30800 \mathrm{kNm} \\
& \mathrm{N}_{\mathrm{ri}}=\mathrm{P}_{\mathrm{ajr}}-\mathrm{P}^{\prime}{ }_{\mathrm{ai}}=131,9 \mathrm{kN}, \Delta \mathrm{M}_{\mathrm{ri}}=\mathrm{N}_{\text {rier }}=131,9 \cdot 32,6=4300 \mathrm{kNmm},
\end{aligned}
$$


$\mathrm{V}_{\mathrm{ri}}=0,5 \cdot 360,1=180 \mathrm{kN}$,

$\Sigma \mathrm{M}_{\mathrm{ri}}=\mathrm{M}_{\mathrm{ri}}-\Delta \mathrm{M}_{\mathrm{ri}}=30800-4300=26500 \mathrm{kNmm}$.

Naprężenia w ściankach wynoszą:

- w przęśle (siła podłużna jest rozciągająca):

$$
\begin{gathered}
\sigma_{\text {max }}=-\frac{\sum M_{r i}}{W_{y, \min }}+\frac{N_{r i}}{A_{r i}}=-\frac{26500 \cdot 10^{3}}{101800}+\frac{131900}{3249}=-219,3 \mathrm{MPa}<355 \mathrm{MPa} \\
\sigma_{\min }=\frac{\sum M_{r i}}{W_{y, \text { max }}}+\frac{N_{r i}}{A_{r i}}=-\frac{26500 \cdot 10^{3}}{236900}+\frac{131900}{3249}=152,5 \mathrm{MPa}<355 \mathrm{MPa}
\end{gathered}
$$

Naprężenie złożone wynosi:

$\sigma_{\text {red }}=\left(\sigma_{\text {max }}^{2}+3 \tau^{2}\right)^{0,5}=\left(219,3^{2}+3 \cdot 90^{2}\right)^{0,5}=269,1 \mathrm{MPa}<355 \mathrm{MPa}$.

- na podporze

$$
\begin{aligned}
& \sigma_{\max }=\frac{\Delta M_{r i}}{W_{y, \min }}+\frac{N_{r i}}{A_{r i}}=\frac{4300 \cdot 10^{3}}{101800}+\frac{131900}{3249}=82,8 \mathrm{MPa}<355 \mathrm{MPa} \\
& \tau=\frac{V_{r i}}{t_{a} \cdot a \sqrt{2}}=\frac{180000}{16 \cdot 88 \sqrt{2}}=90,6 \mathrm{MPa}<\frac{355}{\sqrt{3}}=205,2 \mathrm{MPa}
\end{aligned}
$$

Sprawdzenie nośności ścianek pod obciążeniem $\mathrm{K}_{\mathrm{j}}=202,6 \mathrm{kN}$.

$\mathrm{M}_{\mathrm{rj}}=0,25 \cdot 200 \cdot(360-17)=17150 \mathrm{kNmm}$,

$\mathrm{N}_{\mathrm{rj}}=\mathrm{P}_{\mathrm{air}}-\mathrm{P}_{\mathrm{aj}}^{\prime}=198 \mathrm{kN}, \Delta \mathrm{M}_{\mathrm{rj}}=\mathrm{N}_{\mathrm{aj}} \cdot \mathrm{e}_{\mathrm{r}}=198 \cdot 32,6=6452 \mathrm{kNmm}$,

$\mathrm{V}_{\mathrm{rj}}=0,5 \mathrm{P}^{\prime}{ }_{\mathrm{aj}}=200 / 2=100 \mathrm{kN}$,

$\Sigma \mathrm{M}_{\mathrm{rj}}=\mathrm{M}_{\mathrm{rj}}+\Delta \mathrm{M}_{\mathrm{rj}}=17150+6452=23600 \mathrm{kNmm}$.

Naprężenia w przęśle wynoszą przy ściskającej sile podłużnej:

$$
\begin{aligned}
& \sigma_{\min }=\frac{\sum M_{r i}}{W_{y, \min }}-\frac{N_{r i}}{A_{r i}}=\frac{23600 \cdot 10^{3}}{101800}-\frac{198000}{3245}=171,8 \mathrm{MPa}<355 \mathrm{MPa} \\
& \sigma_{\max }=\frac{\sum M_{r i}}{W_{y, \min }}+\frac{N_{r i}}{A_{r i}}=\frac{23600 \cdot 10^{3}}{236900}+\frac{198000}{3249}=291,8 \mathrm{MPa}<355 \mathrm{MPa} \\
& \tau=\frac{V_{r i}}{t_{a} \cdot a \sqrt{2}}=\frac{100000}{16 \cdot 88 \sqrt{2}}=62,2 \mathrm{MPa}<\frac{355}{\sqrt{3}}=205,2 \mathrm{MPa}
\end{aligned}
$$

$\sigma_{\text {red }}=\left(\sigma_{\text {max }}^{2}+3 \cdot \tau^{2}\right)^{0,5}=\left(291,8^{2}+3 \cdot 62,2^{2}\right)^{0,5}=311,1 \mathrm{MPa}<355 \mathrm{MPa}$.

Sprawdzenie wartości współczynnika $\mathrm{k}_{\mathrm{m}}$ :

$\mathrm{n}=\sigma_{\mathrm{max}} / \mathrm{f}_{\mathrm{yr}}=219,3 / 355=0,618$

$\mathrm{k}_{\mathrm{m}}=1,3 \cdot(1-\mathrm{n})=1,3 \cdot(1-0,618)=0,5<1,0$.

Sprawdzenie środnika wkładki pod obciążeniem lokalnym:

$\mathrm{N}_{\mathrm{i}, \mathrm{Rd}}=436,2 \cdot 0,6724=293,3 \mathrm{kN}>201 \mathrm{kN}$. dłowo.

Wcześniejsze sprawdzenie nośności wkładki było przeprowadzone prawi-

Sprawdzana nośności pasa górnego w węźle dokonuje się w sposób omówiony w [4]. 


\section{Literatura}

[1] Bródka J., Broniewicz M.: Projektowanie konstrukcji stalowych według Eurokodów. PWT. Rzeszów 2013.

[2] Bródka J., Broniewicz M.: Truss design with one-membered elements. and N-joints. XIII International Conference on Metal Structures. Zielona Góra. 15-17 June 2016.

[3] Bródka J., Broniewicz M.: Projektowanie wiązarów z ceowników i kątowników równoramiennych o węzłach typu N. - Inżynieria i Budownictwo. 2016, nr 2.

[4] Bródka J., Broniewicz M.: Design of trusses made of channel sections according to Eurocode rules. "Czasopismo Inżynierii Lądowej, Środowiska i Architektury - Journal of Civil Engineering, Environment And Architecture. JCEEA”, t. XXXII, z. 62 (3/II/15), 2015, pp. 37-61, DOI: 10.7862/rb.2015.139.

[5] Bródka J., Kozłowski A., Ligocki I, Łaguna J., Ślęczka L.: Projektowanie i obliczanie połączeń i węzłów konstrukcji stalowych. PWT. Drugie wydanie. Rzeszów 2013.

[6] Łubiński M., Filipowicz A., Żółtowski W.: Konstrukcje metalowe. Część 1. Arkady. Warszawa 2001.

[7] PN-EN 1090-2: 2007 Wykonanie konstrukcji stalowych i aluminiowych - Część 2: Wymagania techniczne dotyczące wykonania konstrukcji stalowych.

[8] PN-EN 1993-1-1: 2006 Eurokod 3: Projektowanie konstrukcji stalowych - Część 1: Reguły ogólne i reguły dla budynków.

[9] PN-EN 1993-1-8: 2006 Eurokod 3: Projektowanie konstrukcji stalowych - Część 8: Projektowanie węzłów.

[10] Wardenier J., Packer J. A., Zhao X.-L., van der Vegte G. J.: Hollow section in structural applications. Bouven met staal. Zoetemeer 2010.

[11] Rykaluk K.: Konstrukcje stalowe. Podstawy i elementy. Dolnośląskie Wydawnictwo Edukacyjne. Wrocław 2001.

[12] Bródka J., Wojnar A.: Projektowanie wiązarów z ceowników i kątowników równoramiennych o węzłach typu K. Część 1: Węzły pasa dolnego. Czasopismo Inżynierii Lądowej, Środowiska i Architektury - Journal of Civil Engineering, Environment and Architecture, JCEEA, t. XXXIII, z. 63 (3/16), 2016, s. 25-42, DOI:10.7862/rb.2016.183.

\section{DESIGN OF TRUSSES WITH ANGLE BRACE MEMBERS AND CHANNEL SECTION CHORDS, K JOINTS. PART 2. UPPER CHORD TRUSS JOINTS}

\section{S u m m a r y}

The method of connecting of brace members and upper chord of the truss was presented in the article. In the connection of this type, brace members and chord were connected used steel element made from angle section which was welded to the channel section of the chord. The resistance of brace members was calculated during checking of the stability of the truss. The resistance of the connection was calculated according the procedure presented in [12]. The resistance of angle section should be calculated on the assumption the static schema of angle as a simply supported beam under bending and compression (or tension) loaded by concentrated force.

Keywords: steel trusses, designing of trusses joints connecting angle brace members and upper channel section chords, gap $\mathrm{K}$ joints in trusses

DOI:10.7862/rb.2016.244

Przestano do redakcji: $30.09 .2016 r$.

Przyjęto do druku: 20.12.2016 r. 